\title{
Physicochemical Assay of Water of Kashmir Lakes: A Preliminary Comparative Study
}

\author{
Muhammad Aslam Mirza, ", Muhammad Aziz Choudhary ${ }^{1}$, Muhammad Yar Khuhawar², \\ Rafee Arain ${ }^{2}$, Asima Naz ${ }^{1}$, Kauser Yasmeen ${ }^{3}$
}

${ }^{1}$ Department of Chemistry, Mirpur University of Science and Technology (MUST), Mirpur AJK, Pakistan

${ }^{2}$ Institute of Advanced Research Studies in Chemical Sciences, University of Sindh, Jamshoro, Pakistan

${ }^{3}$ Department of Chemistry, Federal Urdu University of Arts, Science and Technology, Karachi, Pakistan

\author{
Email address: \\ ma_mirza64@yahoo.com (M. A. Mirza)
}

\section{To cite this article:}

Muhammad Aslam Mirza, Muhammad Aziz Choudhary, Muhammad Yar Khuhawar, Rafee Arain, Asima Naz, Kauser Yasmeen. Physicochemical Assay of Water of Kashmir Lakes: A Preliminary Comparative Study. American Journal of Environmental Protection. Vol. 4, No. 3, 2015, pp. 152-162. doi: 10.11648/j.ajep.20150403.16

\begin{abstract}
The lakes of Kashmir are generally shallow and situated in flood plans of the river Jhelum. In most of the lakes, thermal stratification is uncommon, and stable stratification occurs only in deeper lakes such as Manabal and Mangla lakes having depth within the range 12-30 m. Anthropogenic contamination of lakes water is one of the concerns that have received attention at local, regional and global levels due to their toxicological impacts and importance in ecosystems. This preliminary study was designed to investigate the comparative physicochemical profile of the water of Mangla, Baghsar and Benjosa lakes of Kashmir. Twenty six parameters including alkalinity, salinity, $\mathrm{pH}$, electrical conductivity (EC), total dissolved solids (TDS), dissolved oxygen (DO), biological oxygen demand (BOD), chemical oxygen demand (COD), total hardness (TH), chloride, sulphate, nitrite, nitrate, phosphate, $\mathrm{Na}, \mathrm{K}, \mathrm{Ca}, \mathrm{Mg}, \mathrm{Fe}, \mathrm{Pb}, \mathrm{Cd}, \mathrm{Ni}, \mathrm{Co}, \mathrm{Zn}$, and $\mathrm{Cu}$ were recorded. Suitability of lakes water for irrigation was checked by using US Salinity diagram, permeability index (PI) and Wilcox diagram. Cluster analysis was carried out to investigate the similarity levels among the selected parameters. Piper's diagram, sodium percentage and residual sodium carbonate (RSC) data served as information tool to understand the ecological status of the water of lakes. COD and BOD patterns in Mangla and Baghsar lakes indicated dual anoxic conditions of the water-rock soil interface and anthropogenic impact while Banjosa showed aerobic activity at the interface. Increasing rate of tourist traffic and greater habitational influence seems to be a major factor contributing towards raising trophic levels of these lakes.
\end{abstract}

Keywords: Kashmir Lakes, Mangla, Baghsar, Banjosa, Physicochemical Study of Lakes

\section{Introduction}

In the broad sense, water quality is determined by numerous biological, physical, and chemical parameters that affect the cachet of water for a meticulous use. In recent years attempts in the country have been made to utilize estuaries, reservoirs and other water bodies for fish culture practices by which the protein uptake for our masses could be increased. Freshwater resources are used to meet the day-today requirements of human settlement, for production of hydropower and most important of all, for agricultural, fisheries and industrial needs. Pakistan has one of the most extensive canal systems in the world. It must be recognized that in under developed and densely populated countries, which have the most pollution problems, the importance of healthy freshwater environment has increased. All the aforementioned activities are expected to have a significant impact on the water quality. The study of limnological dynamics is of great significance in removing the constrictions, which hinder production of inland fish [1-3]. The seasonal variations in physico-chemical factors have a profound effect on the distribution and population density of both fauna and flora [4-9]. In recent years ecosystem of surface water in Kashmir has been disturbed by anthropogenic activities. Free mixing of detergents, grease, oil and animal waste may be considered responsible for the increasing levels of contaminants in the water bodies $[10,11]$. Bioavailability of essential elements enhances the productivity of water that shifts the lake water towards eutrophication [12-17]. The abundance of phytoplankton and 
zooplankton in the freshwater bodies is greatly regulated by the physicochemical factors [18-19] The quality of lake water may be altered by anthropogenic activity, geological nature of the catchments area and yearly rate of the rainfall [20].

Over its lifetime, a lake progresses from a more oligotrophic to a more eutrophic state by collecting essentional nutrients such as phosphorus, nitrogen and sedimentation [21]. Nutrients from agricultural areas, storm water runoff, urban development, fertilized yards and gardens, failing septic systems, land clearing, municipal and industrial wastewater, runoff from construction projects, and recreational activities contribute to accelerated enrichment or eutrophication. Land development, construction and agricultural activities near lakes and streams, or farming steep slopes leave soils vulnerable to erosion and accelerate sedimentation [22]. Like algae, aquatic plants (macrophytes) are a vital part of the lake because they provide cover, habitat and sometimes food for fish, the organisms that fish eat, and other wildlife [23]. Lakes can be contaminated by toxic substances including industrial chemicals such as PCBs (polychlorinated biphenyls), metals, and solvents; pesticides from agricultural runoff; urban storm water runoff containing petroleum hydrocarbons, metals and pesticides; and airdeposited chemicals [24]. Toxic contamination may cause dramatic impacts such as fish kills. Less obvious impacts include decreased reproduction or slower growth rates in fish and reductions in invertebrate diversity [25]. One long-term danger of toxic contamination is the bioaccumulation or build-up of toxic substances--mercury, for example--in fish flesh. The toxic effects may be passed on to humans eating the fish [26].

\subsection{Baghsar Lake}

Baghsar Lake lies at the latitude $32.58^{\circ}$ and longitude $74.8^{\circ}$ and is situated $975 \mathrm{~m}$ above the sea level in Samahni valley of District Bhimber in Azad Jammu \& Kashmir (AJ\&K) Pakistan $^{14}$. Baghsar lake is a tourist spot and lies on the border of mesotrophic to eutrophic nature. It is bounded to Mirpur District in the northwest; and shares border with Indian administrated Kashmir in the northeast and is linked to Pakistan in the west and south. The area is very rich in archaeological remnants. The lake is nearly $1 \mathrm{Km}$ long sheet of water that soothes the senses of the visitors. Its average depth is 3-4 meter and width 15 to 115 meters. The lake is located just in the core of Baghsar village surrounded by mountains. Main source of water for this lake is rainfall; however, water oozes out from its bed too. The average yearly rainfall is $1500 \mathrm{~mm}$ [14].

\subsection{Banjosa Lake}

Banjosa a site of immense scenic beauty, houses a Lake, situated at an altitude of $1981 \mathrm{~m}$ above sea level at about 20 $\mathrm{Km}$ from Rawalakot (elevation1615 m ), the headquarter of district Poonch. Water inflows of this lake are ice melts, spring ooze, and precipitation. The average yearly rainfall is
$1500 \mathrm{~mm}$. The quality of Lake Water may be changed by anthropogenic activity, geological nature of the catchment's areas and yearly degree of precipitation. The lake is periodically drained and recharged to maintain the quality of its water. Khan and Zutshi [27, 28] reported primary productivity and trophic status of Naranbagh Lake and limnological studies on Dal Lake of Kashmir. Leghari et al [29], reported limnological studies of Tatta Pani Hot springs and River Poonch at Tatta village of District Poonch, Kashmir. Mirza et al [9-11] demonstrated the quality of waters of springs, torrents, wells, ponds, snow melt and precipitation in the targeted area. The targeted area of Kashmir stretches between latitude $33^{\circ}-36^{\circ}$ and longitude $73^{\circ}-75^{\circ}$ and the altitude rises sharply from $360 \mathrm{~m}$ to $6325 \mathrm{~m}$ above sea level. There are the hot plains of the Bhimber and Mirpur districts and the coldest lands such as Rawalakot, Leepa and Trarkhal. Weather conditions vary across landscape because of the lofty mountains like the Pirpanjal that check the moisture-laden air from entering the valley. In summers, the outer plains and the outer hills receive rainfall from monsoon winds while in winters, winds from the Mediterranean cause snowfall and rainfall in the Valleys of Kashmir. The moisture-laden winds cause rainfall in the forests on the hills pushing the temperature down in summer.

\subsection{Mangla Lake}

Mangla Lake is the $16^{\text {th }}$ largest artificial lake in the world. It was built from 1961 to 1967 across the Jhelum River. It lies at about $108 \mathrm{Km}$ south-east of Islamabad in Mirpur District of Azad Kashmir, Pakistan. The main edifice of the lake consists of 2 spillways, 5 power-cum-irrigation tunnels, 4 embankment lakes and a 1,000 MW power station. The main dam is $10,3,100 \mathrm{~m}$ long and $138 \mathrm{~m}$ high with a reservoir of $97,250 \mathrm{Km}^{2}$. Since its first sequestration in 1967 , sedimentation has increased to the extent of $1.39 \mathrm{Km}^{3}$, and at present the gross storage capacity has declined to $5.86 \mathrm{Km}^{3}$ from the actual design of $7.25 \mathrm{Km}^{3}$. The live capacity has declined to $5.65 \mathrm{Km}^{3}$ from $6.59 \mathrm{Km}^{3}$. This implies a reduction of $19.22 \%$ in the capacity of the lake.

\subsection{Geology}

All the selected lakes are situated in mountainous area except Mangla Lake that is placed in fairly plan area. Ecological study of the area was carried out by Meddlicott, Lydekker and Mddlemiss [30-32]. Siwalik group of rocks is found mostly in the western part of the Poonch District along with the eastern bank of the Jhelum River. These rocks crop out between Azad Pattan and Kohala. An irregular eastern contact runs from Hajeera through Rawalkot to Dhirkot. Wadia divided the Siwaliks of Kahmir into Lower Palandri, Middle Mang and Upper Sand Rock Stage [33]. Chaudhry and Ashraf reported in Kotli area, the rocks consist of granite and crystalline groups [34]. The rocks of the study area are mainly made of chlorite, muscovite mica granite, sand stone, schists, quartzite, pyrite and calcite. The fractured mica schists inter-bedded with thin bends of granite gneiss, 
quartzite, and non-foliated granitic rocks act as a barrier to the ground water flow, forming springs. A permeable recharge zone for groundwater is provided by fractured mica schists covered with thin layer of top soil $(0.5-1.5 \mathrm{~m})$ in this area $[35,36]$.

\section{Experimental}

\subsection{Sampling Strategy}

Prior to efficient sampling the lakes were observed for their locations and stratified for their sampling. Each stratum was sampled for predetermined number of sub samples. The sub samples were mixed to form composite samples. The samples were also in situ tested for basic physico-chemical parameters as temperature, $\mathrm{pH}, \mathrm{DO}, \mathrm{TDS}$ and EC. The sampling mode was simple grab method. High density polythene bottles (pre-washed) were suspended, at predetermined depths through a Secchi disc, from the surface and stopper removed by a sharp jerk through an attached line. The Lakes were navigated by boat. For elemental analysis each sample was acidified to $\mathrm{pH}<2$; for organic matter, fixed with $\mathrm{HgCl}_{2}$. Separate samples were taken for specific analysis.

For sediment sample collection, clean, free of rust and chrome plated hand probe and spade were used. Simple random procedure was adopted for the collection of samples. With this system each soil core was selected separately, randomly and independently of previously drawn units. Individual soil cores taken from 10 locations for each composite sample were mixed thoroughly in clean plastic containers. A sample of the soil mixture was removed as the composite sample and placed in a soil sample bag, lined with plastic. This composite sample consisted of a mixture of the individual cores.

\subsection{Measurements}

Hardness, chloride and alkalinity were determined by titration with standard EDTA, silver nitrate and hydrochloric acid. Conductivity, salinity and total dissolved solids (TDS) were evaluated with Orion 115 conductivity meter. The $\mathrm{pH}$ was recorded with Orion $420 \mathrm{~A} \mathrm{pH}$ meter. The dissolved oxygen (DO) in the samples was determined by Wrinkler method (APHA, 1989). Chemical oxygen demand (COD) was estimated by micro-dichromate oxidation method. Kjeldahl nitrogen was determined by using standard procedure [37]. Orthophosphate, nitrate and nitrite were determined by spectrophotometery. Orthophosphate was determined by reducing phosphomolybdic acid formed with ascorbic acid to molybdenum blue. Total phosphate was estimated by persulphate acid hydrolysis, followed by determination as for orthophosphate. Nitrate was determined after derivatization with brucine sulphate. Nitrite was estimated using $\mathrm{N}$-naphthyl ethylenediamine as derivatizing reagent as reported [37]. Sulphate was determined by turbidimetery as $\mathrm{BaSO}_{4}$ using Hitachi 220 spectrophotometer. A method developed by the International Humic Substance Society (IHSS) was used for the extraction of humic substances from soil samples (Stevenson, 1982). The metal ions $\mathrm{Na}, \mathrm{K}, \mathrm{Ca}, \mathrm{Mg}, \mathrm{Fe}, \mathrm{Pb}, \mathrm{Cu}, \mathrm{Zn}, \mathrm{Ni}, \mathrm{Cd}$, and $\mathrm{Co}$ were determined with Varian Spectr AA-20 atomic absorption spectrometer with standard burner head and air acetylene flame at the conditions recommended by the manufacturer. The analysis was carried out in triplicate with integration time $3 \mathrm{sec}$. and delay time $3 \mathrm{sec}$. $\mathrm{Na}, \mathrm{K}, \mathrm{Ca}$ and $\mathrm{Mg}$ were determined after appropriate dilution. Sample $(350 \mathrm{~mL})$ containing nitric acid $(1 \mathrm{~mL})$ was heated gently at $90-95{ }^{\circ} \mathrm{C}$ and was concentrated to about $5-8 \mathrm{~mL}$. The solution was transferred to volumetric flask and final volume was adjusted to $15 \mathrm{~mL}$. The solution was analyzed for the contents of $\mathrm{Fe}$, $\mathrm{Pb}, \mathrm{Cu}, \mathrm{Zn}, \mathrm{Ni}, \mathrm{Cd}$, and $\mathrm{Co}$ by air acetylene flame atomic absorption spectrometer.

\section{Results and Discussion}

\subsection{Chemical Characteristics of Lake Waters; pH, EC, TDS, $T H, D O, B O D \& C O D$}

The water in Mangla Lake (Fig.1) is slightly alkaline (pH 7.5) in summer and autumn and slightly acidic $(\mathrm{pH} \mathrm{6.1)} \mathrm{in}$ winter. Baghsar and Banjosa lake waters are acidic in summer $(\mathrm{pH} 6.5 \& \mathrm{pH} 6.6)$ and alkaline in autumn and winter $(\mathrm{pH} 7.09,7.1 \& \mathrm{pH} 7.13$; 7.99). Over a hydrological year the inter season variance for Mangla is 0.567, Baghsar 0.117 and Banjosa 0.567. TDS, EC, TH, values also concomitantly decrease or increase with a corresponding change in $\mathrm{pH}$. These trends indicate moderate photosynthesis activity and chemical weathering of lithologic limestone and dilution by precipitation or concentration through evatranspiration. Likewise, lower DO, BOD, COD values in all the lakes negate inputs from anthropogenic activity but indicate deeper anaerobic activity at water-bed rock interface (Fig.1).

\subsection{Nitrogen, Phosphorus, Hardness, Alkalinity and Salinity}

Nitrite- N, nitrate-N and Kjeldahl-N were determined in samples of Banjosa, Mangla and Bhaghsar Lakes; values observed were found in the range $0.001-0.007 \mathrm{mg} / \mathrm{L}, 2.66-$ $3.24 \mathrm{mg} / \mathrm{L}$ and $0.19-5.89 \mathrm{mg} / \mathrm{L}$ respectively. Higher concentrations of Kjeldahl-N may be attributed to industrial and domestic sewage of Mirpur city in Mangla Lake and biomass degradation in Banjosa Lake. Banjosa, Mangla and Bhaghsar Lakes indicated orthophosphate and acid hydrolysable phosphate within the range $0.06-0.16 \mathrm{mg} / \mathrm{L}$ and $0.07-0.20 \mathrm{mg} / \mathrm{L}$ respectively reflecting the deficiency of phosphate into earth crust of the targeted area. Hardness, alkalinity and salinity were observed within the range 131$226 \mathrm{mg} / \mathrm{L}, 113-211 \mathrm{mg} / \mathrm{L}$ and $0.1-0.2 \mathrm{mg} / \mathrm{L}$ for all the three Lakes (Table 1). 


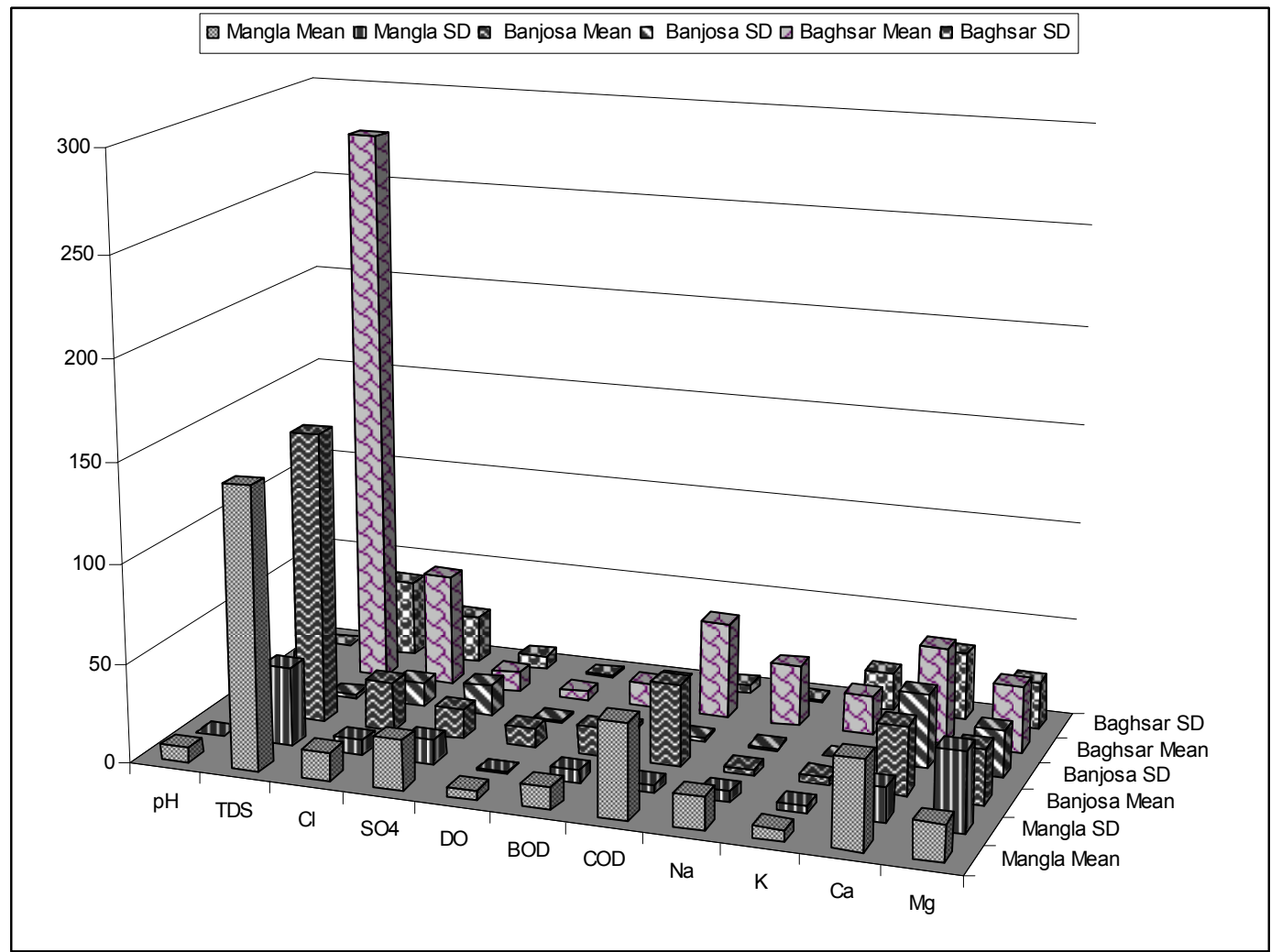

Fig. 1. Comparative study of $\mathrm{pH}, \mathrm{TDS}, \mathrm{Cl}$, $\mathrm{SO}_{4}, \mathrm{DO}, \mathrm{BOD}, \mathrm{COD}, \mathrm{Na}, \mathrm{K}, \mathrm{Ca}$, and $\mathrm{Mg}$ contents in Lakes of Kashmir.

Table 1. Results of Physicochemical Parameters of Lakes of AJ\&K.

\begin{tabular}{llll}
\hline Parameters & Mangla Lake & Banjosa Lake & Baghsar Lake \\
\hline Salinity g/L & $0.10 \pm 0.041$ & $0.10 \pm 0.011$ & $0.20 \pm 0.015$ \\
M. Alkalinity mg/L & $113 \pm 18.61$ & $135 \pm 27.51$ & $211 \pm 46.61$ \\
Hardness as CaC0 ${ }_{3} \mathrm{mg} / \mathrm{L}$ & $131 \pm 126.21$ & $172 \pm 12.61$ & $226 \pm 36.61$ \\
Nitrite $-\mathrm{N} \mathrm{mg/L}$ & $0.004 \pm 0.001$ & $0.001 \pm 0.0004$ & $0.007 \pm 0.002$ \\
Nitrate- $\mathrm{N} \mathrm{mg/L}$ & $3.24 \pm 1.24$ & $2.82 \pm 1.05$ & $2.66 \pm 1.02$ \\
K- Nitrogen mg/L & $5.89 \pm 2.11$ & $1.35 \pm 0.31$ & $0.19 \pm 0.06$ \\
Orthophosphate $\mathrm{mg} / \mathrm{L}$ & $0.15 \pm 0.03$ & $0.16 \pm 0.02$ & $0.06 \pm 0.008$ \\
Total Phosphate $\mathrm{mg} / \mathrm{L}$ & $0.20 \pm 0.046$ & $0.20 \pm 0.015$ & $0.07 \pm 0.04$ \\
\hline
\end{tabular}

\subsection{Major Elemental Distributions}

(i). Cations: $\mathrm{Ca}$ emerges as the major cationic load contributor in all three lakes; Mangla 52\%, Banjosa $49.7 \%$ and Baghsar $36.5 \%$. Second in donor rank are $\mathrm{Mg}$ and $\mathrm{Na}$ contributing about $25 \%$ to Mangla and Baghsar lake loads while for Banjosa $40 \%$ is contributed by $\mathrm{Mg}$ and fewer than $5 \%$ by $\mathrm{Na}$. The order of cation distribution for Mangla lake water is $\mathrm{Ca}-\mathrm{Mg}-\mathrm{Na}-\mathrm{K}$ for Banjosa $\mathrm{Ca}-\mathrm{Mg}-\mathrm{K}-\mathrm{Na}$, and that for Baghsar is Ca-Mg-Na-K (Pipers plot). $\mathrm{Na}$ is higher for Mangla (19.4\%) and Baghsar (23.2\%) where most of the anthropogenic activity is centered and both are drained by rivers carrying surface and mountain run offs (Table 2).

(ii). Anions: Anionic concentration is dominated by $\mathrm{HCO}_{3} / \mathrm{CO}_{3}$, followed by chlorides, sulphates and trace nitrates. This trend pertains to all three lakes. The metal speciation is anticipated as $\mathrm{Ca}-\mathrm{HCO}_{3} / \mathrm{CO}_{3}>\mathrm{Mg}-\mathrm{HCO}_{3} / \mathrm{CO}_{3}>$ $\mathrm{Na}-\mathrm{HCO}_{3}, \mathrm{Na}-\mathrm{Cl}>\mathrm{K}-\mathrm{Cl}>\mathrm{Ca}-\mathrm{SO}_{4}>\mathrm{Mg}-\mathrm{SO}_{4}$. Insignificant presence is also indicated for $\mathrm{NO}_{2}-\mathrm{N}, \mathrm{NO}_{3}-\mathrm{N}$; Mangla Lake indicates $4.2 \mathrm{mg} / \mathrm{L}$ Banjosa $1.35 \mathrm{mg} / \mathrm{L}$ and Baghsar 0.57
mg/L. Though the Mangla and the Baghsar receive considerable domestic waste water but K-Nitrogen data demonstrates substantial dilution by precipitation. The overall quantity of carbonate alkaline earth type and $\mathrm{Cl}-$ group (nominal anthropogenic activity) and is maintained by precipitation dilution (Table 2).

Table 2. Results of physicochemical parameters of Lakes of $A J \& K$.

\begin{tabular}{llll}
\hline Parameters & $\begin{array}{l}\text { Mangla Lake } \\
\text { Mean (SD) }\end{array}$ & $\begin{array}{l}\text { Banjosa Lake } \\
\text { Mean (SD) }\end{array}$ & $\begin{array}{l}\text { Baghsar Lake } \\
\text { Mean (SD) }\end{array}$ \\
\hline $\mathrm{pH} 25^{\circ} \mathrm{C}$ & $7.03 \pm 0.75$ & $7.25 \pm 0.73$ & $6.89 \pm 0.34$ \\
$\mathrm{EC} \mu \mathrm{S} / \mathrm{cm}$ & $223 \pm 26.5$ & $232 \pm 13.4$ & $459 \pm 31.8$ \\
$\mathrm{TDS} \mathrm{mg} / \mathrm{L}$ & $142 \pm 40.06$ & $148 \pm 1.41$ & $283.2 \pm 38.97$ \\
$\mathrm{Cl}^{-} \mathrm{mg} / \mathrm{L}$ & $14.29 \pm 7.64$ & $24.63 \pm 12.65$ & $57.13 \pm 24.2$ \\
$\mathrm{SO}_{4} \mathrm{mg} / \mathrm{L}$ & $25.40 \pm 12.02$ & $15.32 \pm 15.38$ & $10.12 \pm 7.04$ \\
$\mathrm{DO} \mathrm{mg} / \mathrm{L}$ & $4.64 \pm 0.62$ & $10.06 \pm 1.41$ & $4.39 \pm 0.73$ \\
$\mathrm{BOD} \mathrm{mg} / \mathrm{L}$ & $11.52 \pm 6.60$ & $14.80 \pm 1.41$ & $12.6 \pm 1.65$ \\
$\mathrm{COD} \mathrm{mg} / \mathrm{L}$ & $48.00 \pm 4.00$ & $41.33 \pm 1.53$ & $49.00 \pm 4.24$ \\
$\mathrm{Na} \mathrm{mg} / \mathrm{L}$ & $16.79 \pm 5.78$ & $3.09 \pm 0.99$ & $30.94 \pm 1.08$ \\
$\mathrm{~K} \mathrm{mg} / \mathrm{L}$ & $5.83 \pm 3.70$ & $4.01 \pm 1.42$ & $19.53 \pm 19.9$ \\
$\mathrm{Ca} \mathrm{mg} / \mathrm{L}$ & $45.01 \pm 17.61$ & $34.52 \pm 37.47$ & $48.54 \pm 34.45$ \\
$\mathrm{Mg} \mathrm{mg} / \mathrm{L}$ & $18.77 \pm 40.01$ & $27.80 \pm 24.15$ & $33.94 \pm 23.8$ \\
\hline
\end{tabular}




\subsection{Trace Metals}

Trace metals constitute only $0.93 \%$ of TDS in Baghsar, $0.75 \%$ of TDS in Mangla and $1.2 \%$ of TDS in Banjosa. The ratio of trace metals for Baghsar:Mangla is 0.405, Mangla : Banjosa is 0.601 and Banjosa : Mangla is 0.67.

$\mathrm{Pb}$ and $\mathrm{Co}$ dominate the minor elemental presence. $\mathrm{Pb}$ contributing $34 \%$ in Mangla. $39.9 \%$ in Baghsar and to $50 \%$ in Banjosa, while Co is $25.3 \%$ in Baghsar, $73.5 \%$ in Mangla and $4.4 \%$ in Banjosa. They form of $5 \%$ COD in Baghsar, $2.2 \%$ in Mangla and $4.4 \%$ Banjosa. All the preceding comparisons of lakes bring about a number inferences: only about $1 \%$ of TDS is made up of trace metals of which lake wise $\mathrm{Pb}$ is from $34-50 \%$ and that for Co the change is from $5-73.5 \%$.

The trace metals constitute only $0.93 \%$ of TDS in Baghsar, $0.75 \%$ of TDS in Mangla and $1.2 \%$ of TDS in Banjosa. $\mathrm{Pb}$ and $\mathrm{Co}$ dominate trace elemental presence; $\mathrm{Pb}$ contributes $34 \%$ in Mangla; $39.9 \%$ in Baghsar; $50 \%$ of TDS in Banjosa while Co is $25.3 \%$ in Baghsar; $73.5 \%$ Mangla and $4.4 \%$ of TDS in Banjosa. There is also a marginal change in $\mathrm{Cd}$ Concentration (Table 3).

Table 3. Trace metals data of lakes of Kashmir.

\begin{tabular}{llll}
\hline Parameters & Mangla Lake & Banjosa Lake & Baghsar Lake \\
\hline $\mathrm{Fe} \mathrm{mg/L}$ & $0.008 \pm 0.002$ & $0.027 \pm 0.012$ & $0.018 \pm 0.005$ \\
$\mathrm{~Pb} \mathrm{mg} / \mathrm{L}$ & $0.037 \pm 0.003$ & $0.090 \pm 0.014$ & $0.087 \pm 0.013$ \\
$\mathrm{Cu} \mathrm{mg} / \mathrm{L}$ & $0.001 \pm 0.0004$ & $0.001 \pm 0.0005$ & $0.058 \pm 0.010$ \\
$\mathrm{Zn} \mathrm{mg} / \mathrm{L}$ & $0.023 \pm 0.007$ & $0.036 \pm 0.008$ & $0.012 \pm 0.003$ \\
$\mathrm{Ni} \mathrm{mg} / \mathrm{L}$ & $0.031 \pm 0.015$ & $0.020 \pm 0.011$ & $0.017 \pm 0.006$ \\
$\mathrm{Cd} \mathrm{mg} / \mathrm{L}$ & $0.007 \pm 0.001$ & $0.004 \pm 0.002$ & $0.005 \pm 0.002$ \\
$\mathrm{Co} \mathrm{mg} / \mathrm{L}$ & $0.079 \pm 0.031$ & $0.069 \pm 0.041$ & $0.067 \pm 0.021$ \\
\hline
\end{tabular}

\subsection{Soil Organic Matter}

Baghsar Lake soil analysis revealed the presence of total organic matter (TOM), humic acid (HA), fulvic acid (FA) and non-humic substances (NHS) $0.210 \mathrm{~g}, 31 \%, 33 \%$, and $36 \%$ respectively. The results obtained from Banjosa lake soil were $0.228 \mathrm{~g}$ TOM, $34 \% \mathrm{HA}, 36 \%$ FA and $30 \%$ NHS whereas, Mangla lake soil indicated TOM $0.102 \mathrm{~g}$, HA $35 \%$, FA $24 \%$, and NHS $41 \%$. Moisture content in Baghsar, Banjosa and Mangla soil samples was observed $27 \%, 25 \%$ and $19 \%$ respectively. Based on the percentage ratio of HA and FA, the soils of Baghsar, Mangla and Banjosa were categorized as gray forest, sodpodzolic and gray forest respectively after Kononova [36].

\section{Water Suitability for Irrigation}

\subsection{Hazards of Alkalinity and Salinity}

The Lake water samples were also tested regarding their suitability as irrigation water. Two parameters TDS, EC were specifically monitored as these are lineally correlated and are a measure of salinity hazard to crops. TDS values of all samples indicate that lake water is of fresh nature (Table 4) while EC based classification places 2 lakes in excellent and 1 in good class (Table 5).

Since it reduces osmotic activity of plants and interferes with the absorption of nutrients [37,38], sodium adsorption ratio (SAR) was specifically calculated to determine the suitability of lake water for irrigation [39]. The SAR values range from $0.55-4.82$ with an average value of 2.78 during one hydrological year. As lake water samples of the study area fall in the low sodium class A1 (Table 6) (Fig. 2), it implies that no alkali hazard is anticipated to the crops. If the SAR value is greater than 6-9, the irrigation will cause permeability problems on shrinking and swelling types of clays $[40,41]$.

Table 4. Nature of lake water based on TDS values.

\begin{tabular}{llll}
\hline TDS $\mathbf{~ m} / \mathbf{L}$ & Nature of water & Representing lakes & No. of lakes \\
\hline$<1000$ & Fresh water & Baghsar, Mangla, Banjosa & 3 \\
$1000-10000$ & Brackish water & Nill & Nill \\
$10000-100000$ & Saline water & Nill & Nill \\
$>100000$ & Brine water & Nill & Nill \\
\hline
\end{tabular}

Table 5. Classification of irrigation (lake) water based on electrical conductivity (EC).

\begin{tabular}{llll}
\hline $\mathbf{E C}(\boldsymbol{\mu} \mathbf{S} / \mathbf{c m})$ & Water class & Hydrological year (2004-2005) Representing lakes & Total no. of lakes \\
\hline$<250$ & Excellent & Mangla, Banjosa & 2 \\
$250-750$ & Good & Baghsar & 1 \\
$750-2000$ & Permissible & Nil & Nil \\
$2000-3000$ & Doubtful & Nil & Nil \\
$>3000$ & Unsuitable & Nil & Nil \\
\hline
\end{tabular}

Table 6. Classification of lake based on alkalinity hazard.

\begin{tabular}{lllll}
\hline SAR & Alkalinity hazard & Water class & Hydrological year (2004-2005) Representing lakes & Total no. of lakes \\
\hline$<10$ & A1 & Excellent & Baghsar, Mangla, Banjosa & 3 \\
$10-18$ & A2 & Good & Nil & Nil \\
$18-26$ & A3 & Doubtful & Nil & Nil \\
$>26$ & A4 & Unsuitable & Nil & Nil \\
\hline
\end{tabular}




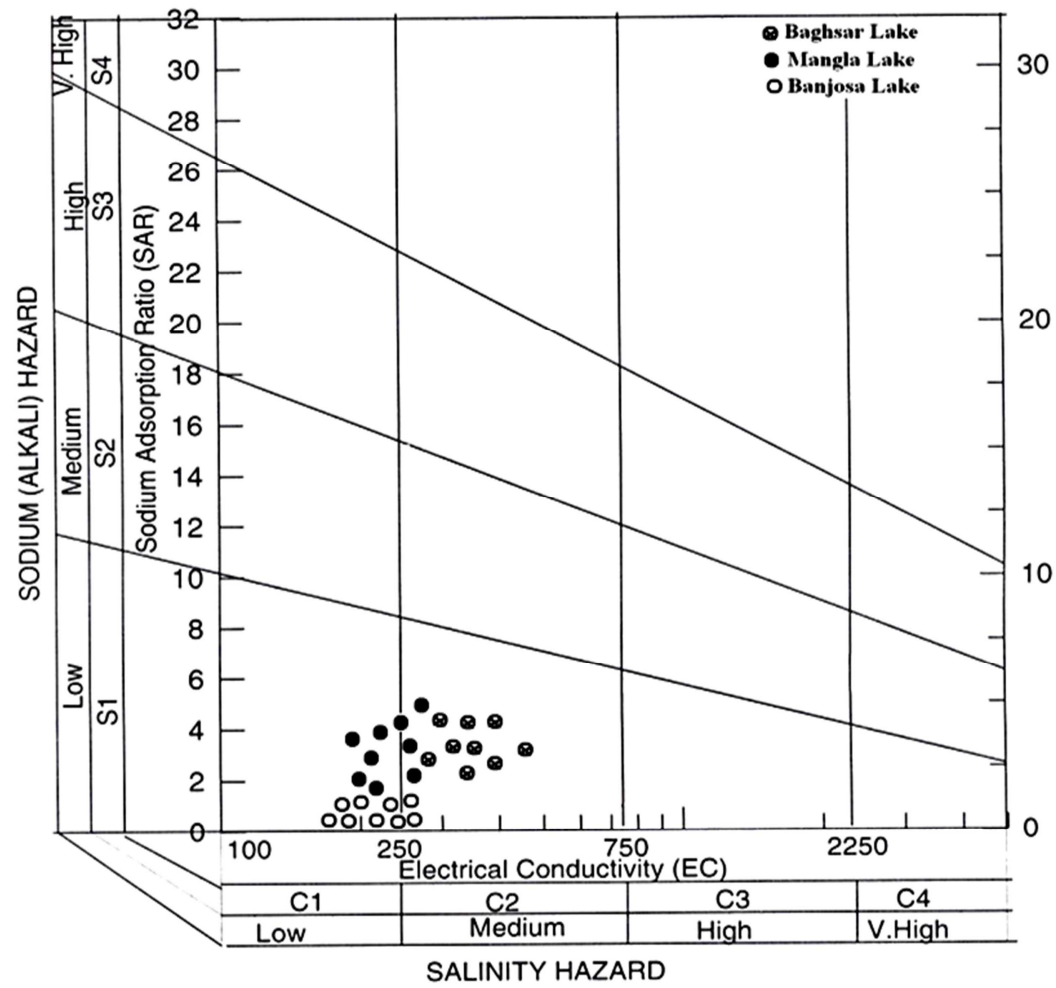

Fig. 2. Salinity and alkalinity hazard in lake water in US salinity diagram.

\subsection{Sodium Concentration (Percentage)}

The sodium percentage ( $\mathrm{Na} \%$ ) was also calculated. The sodium \% (Table 7) indicates that the lake water is excellent
(Mangla) to good (Baghsar, Banjosa) for irrigationand meets USDA standards [42] (Fig.3).

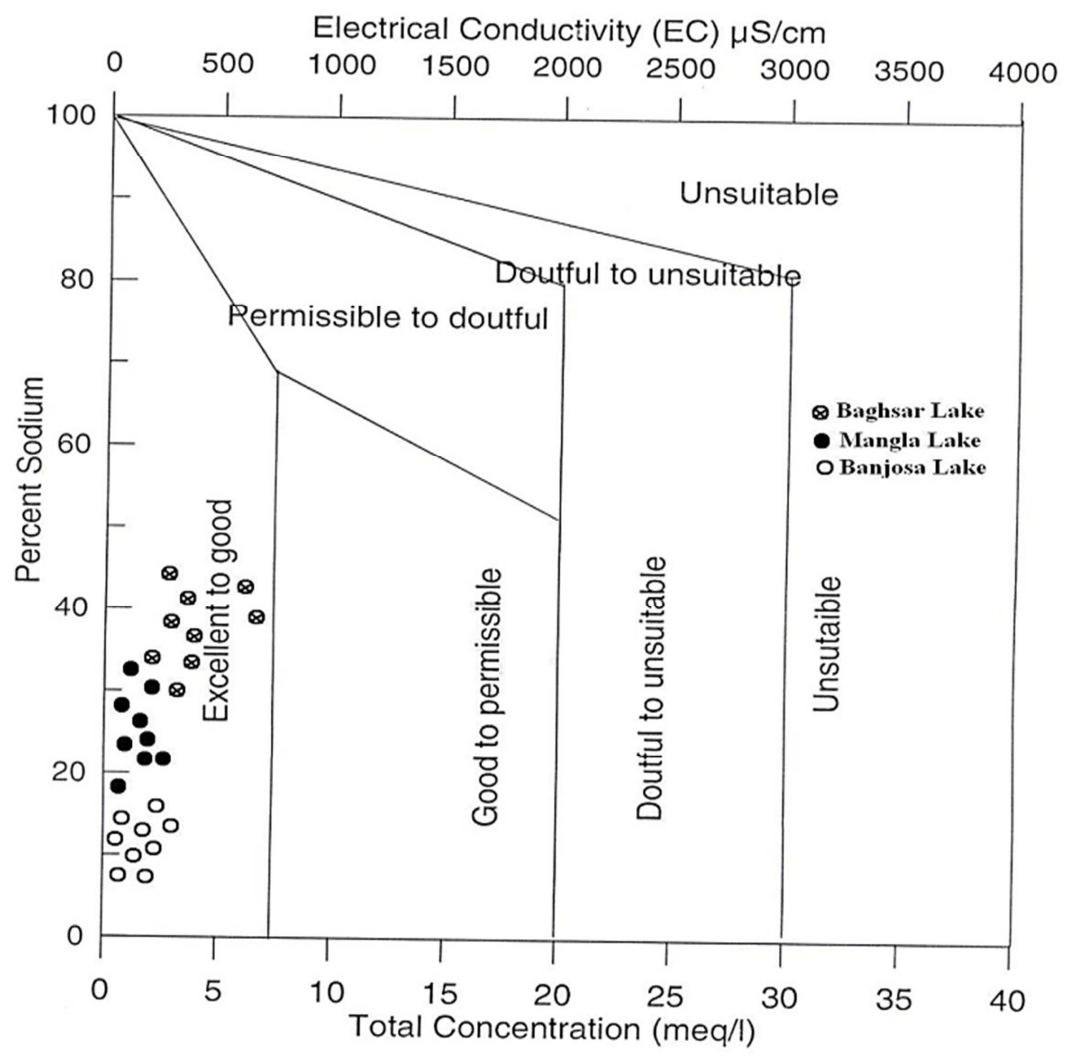

Fig. 3. Suitability of lakes water for irrigation in Wilcox diagram. 
Table 7. Quality of irrigation water based on $\% \mathrm{Na}$.

\begin{tabular}{llll}
\hline$\% \mathbf{~ N a}$ & Water class & Hydrological year (2004-2005) Representing lakes & Total no. of lakes \\
\hline$<20$ & Excellent & Mangla & 1 \\
$20-40$ & Good & Baghsar, Banjosa & 2 \\
$40-60$ & Permissible & Nil & Nil \\
$60-80$ & Doubtful & Nil & Nil \\
$>80$ & Unsuitable & Nil & Nil \\
\hline
\end{tabular}

\subsection{Permeability Index (PI)}

If the concentration of sodium ions is high in irrigation water, they get absorbed by clay particles, displacing $\mathrm{Ca}^{2+}+$ $\mathrm{Mg}^{2+}$ ions reducing permeabilityand eventually resulting in poor internal drainage $[41,43,44]$.

The Permeability Index (PI) was calculated and for samples in the present work PI ranges from $22.5 \%$ to $40.07 \%$ in a hydrological year. The average value is $32.2 \%$ that comes under class-II of Donen's chart making it good for cropping. While \% $\mathrm{Na}$ categorizes 1 lake (Mangla) as excellent and 2 lakes (Baghsar, Banjosa) as good, none of them as doubtful (Table 8) (Fig.4).

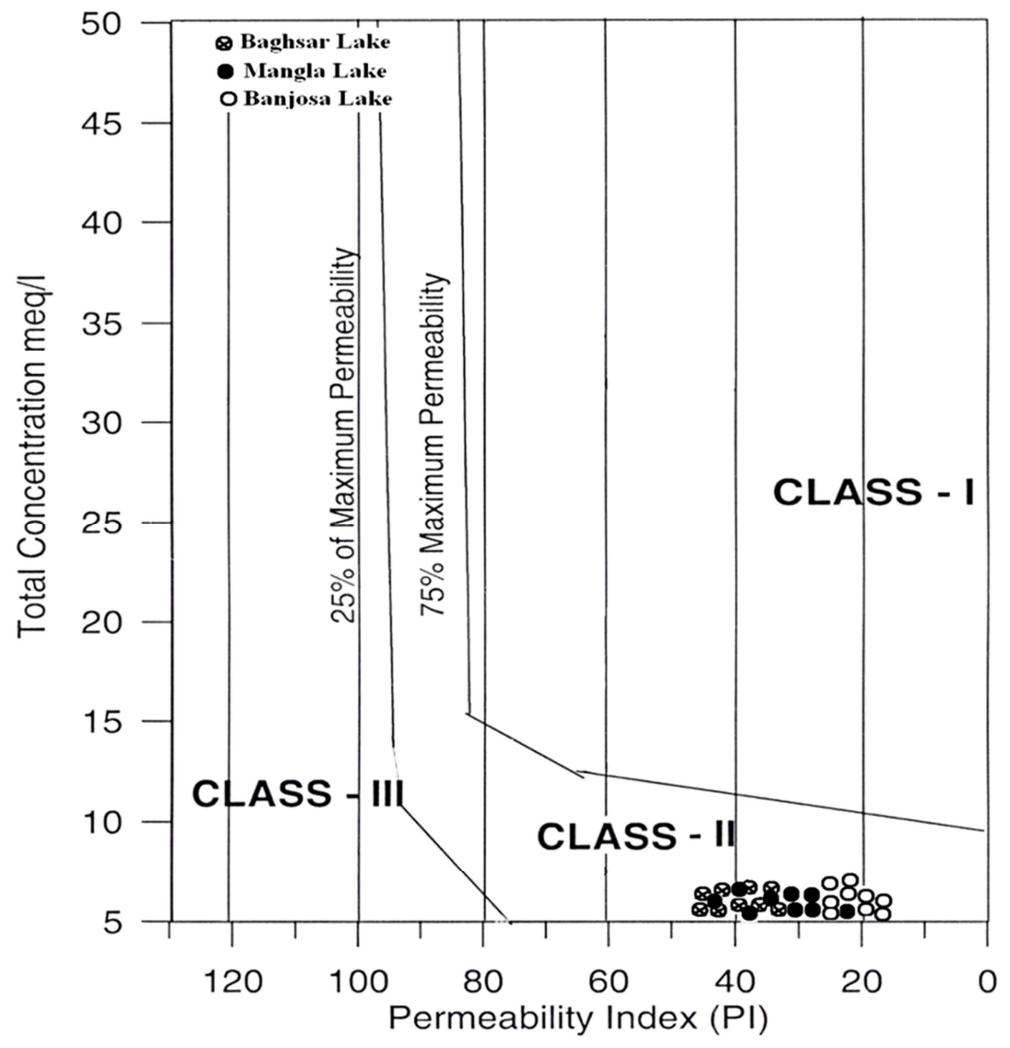

Fig. 4. Suitability of lakes water for irrigation based on PI.

The application of these two parameters (Na \% \& PI) indicate that permeability index renders only none sample as unsuitable for irrigation and the $\% \mathrm{Na}$ puts no sample as border line indicating that the concentration of sodium is not high enough to render the water unsuitable for irrigation. Total hardness also indicates that hardness of water is mainly due to carbonates and bicarbonates of calcium and magnesium, 1 sample moderate and 2 hard (Table 8).

Table 8. Hardness based classification of the lake water.

\begin{tabular}{lll}
\hline $\begin{array}{l}\text { Total hardness as } \mathbf{C a C O 3} \\
\mathbf{m g} / \mathbf{L}\end{array}$ & Water class & Representing lakes \\
\hline$<75$ & soft & Nil \\
$75-150$ & Moderately hard & Mangla \\
$150-300$ & Hard & Baghsar, Banjosa \\
$>300$ & Very hard & Nil \\
\hline
\end{tabular}

\subsection{Residual Sodium Carbonate (RSC)}

Residual Sodium Carbonate test places the samples in good category of lake water giving it a value of $0.1-0.851$ i.e. $<1.25$ for 3 lakes; none of the lakes fall in doubtful and unsuitable category [45] (Table 9).

Table 9. Classification of irrigation water based on residual sodium carbonate.

\begin{tabular}{llll}
\hline $\begin{array}{l}\text { RSC } \\
\text { (meq/L) }\end{array}$ & $\begin{array}{l}\text { Water } \\
\text { quality }\end{array}$ & $\begin{array}{l}\text { Hydrological year (2008- } \\
\text { 2009) Representing lakes }\end{array}$ & $\begin{array}{l}\text { Total no. of } \\
\text { lakes }\end{array}$ \\
\hline$<1.25$ & Good & Baghsar, Mangla, Banjosa & 3 \\
$1.25-2.5$ & Doubtful & Nil & Nil \\
$>2.5$ & Unsuitable & Nil & Nil \\
\hline
\end{tabular}




\subsection{Hydrochemical Profile}

In Piper's diagram, major cation-anion distribution indicates $\mathrm{Ca}$ as the predominant ion $\mathrm{Ca}-\mathrm{HCO}_{3}$ followed by $\mathrm{Mg}-\mathrm{HCO}_{3}$. The order being $\mathrm{Ca}-\mathrm{Mg}-\mathrm{HCO}_{3}>\mathrm{Na}-\mathrm{K}-\mathrm{HCO}_{3}$; for chlorides the distribution is mixed $\mathrm{Ca}-\mathrm{Na}-\mathrm{Mg}-\mathrm{K}-\mathrm{Cl}$. The nature of water (Mangla Lake) is more of Ca-Mg- $\mathrm{Cl} / \mathrm{NO}_{3}$ type because of anthropogenic activity from Mirpur city (Fig. 5). The $\mathrm{SO}_{4}$ ions show a little presence because of a fewer industries and lake of sulphur deposits in the area.

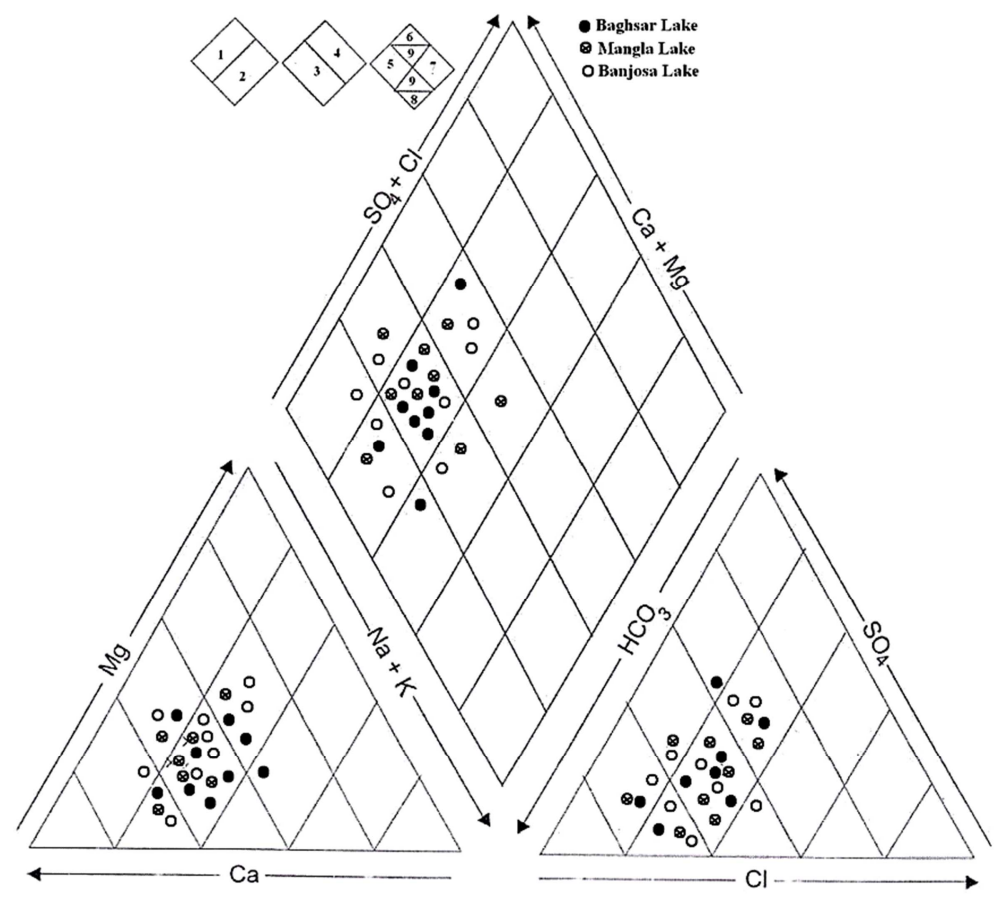

Fig. 5. Hydrochemical profile of lakes water in Piper diagram.

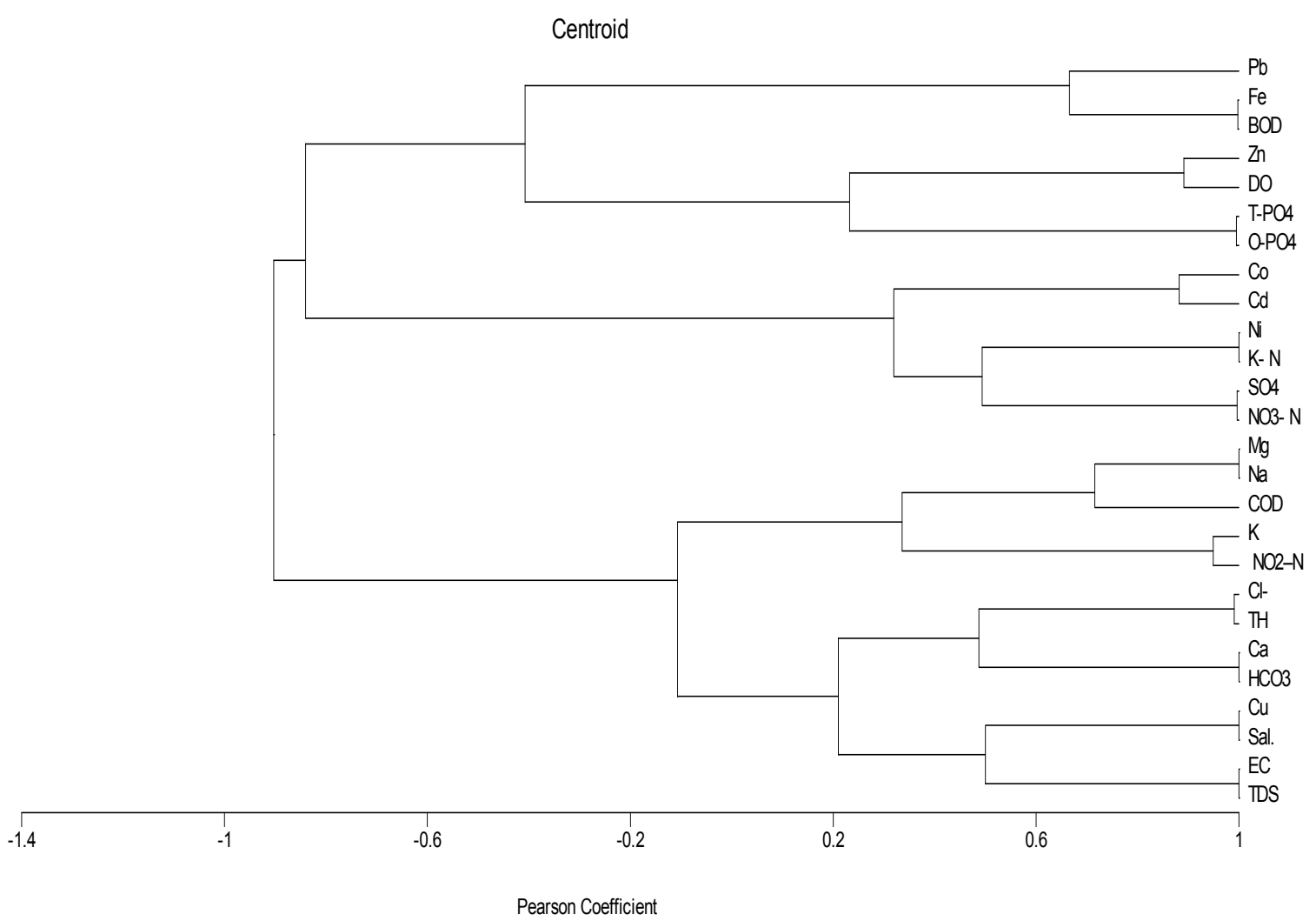

Fig. 6. A dandrogram showing cluster analysis of lakes water in Kashmir. 


\subsection{Cluster Analysis of Lakes Water}

Cluster analysis of 26 parameters including major and trace metals in the water samples was carried out in order to investigate the multivariate distribution as shown in Fig. 6. Five clusters were observed for altogether 26 parameters in water samples; close association of $\mathrm{Pb}, \mathrm{Fe}$ and $\mathrm{BOD}$ with the $\mathrm{Zn}, \mathrm{DO}, \mathrm{O}-\mathrm{PO}_{4}$ and $\mathrm{T}-\mathrm{PO}_{4}$ in the water shown by first two clusters implied that most of the inputs were associated with the anthropogenic activities with special reference to the Baghsar and Mangla Lakes which are situated within thickly populated areas. Third cluster comprising of $\mathrm{Co}-\mathrm{Cd}$, NiKjeldahl nitrogen, and sulfate-nitrate nitrogen showed similar trend of these parameters in the hydrolitho-environment. The anthropogenic contributions were shown by the forth cluster consisting of $\mathrm{Na}, \mathrm{Mg}, \mathrm{COD}, \mathrm{K}$ and $\mathrm{NO}_{2}-\mathrm{N}$ which might be contributed by the agricultural activities as well as dry deposition of the suspended particulates. Fifth cluster showed close association among six parameters subdivided in to two clusters with three parameters each $\left(\mathrm{Cl}^{-}-\mathrm{TH}-\mathrm{Ca}-\mathrm{HCO}_{3}\right.$ and
Cu-Sal-EC-TDS) showing predominant contributions of geological formations.

\subsection{Correlation Coefficient Matrix (r) of selected Metals}

The data on correlation matrix between selected metals is shown in table 10 and the significant $r$-values at $p<0.05$ are made bold. Very strong correlations were observed between the following elemental pairs: $\mathrm{Mg}-\mathrm{Na}(\mathrm{r}=1.00)$, Co-Ni $(\mathrm{r}=0.999)$ whereas $\mathrm{K}-\mathrm{Na}(\mathrm{r}=0.890)$, Ca-K $(\mathrm{r}=0.911)$, Mg-K $(\mathrm{r}=0.884), \quad \mathrm{Pb}-\mathrm{Fe} \quad(\mathrm{r}=0.904), \quad \mathrm{Cu}-\mathrm{Na} \quad(\mathrm{r}=0.779), \quad \mathrm{Cu}-\mathrm{K}$ $(\mathrm{r}=0.979), \quad \mathrm{Cu}-\mathrm{Ca} \quad(\mathrm{r}=0.975), \quad \mathrm{Cu}-\mathrm{Mg} \quad(\mathrm{r}=0.772), \quad \mathrm{Cd}-\mathrm{Ni}$ $(\mathrm{r}=0.859)$ and $\mathrm{Co}-\mathrm{Cd}(\mathrm{r}=0.882)$ showed strong correlation depicting lithogenically linked interactions or common anthropogenic contamination sources. The metal pairs with negative $\mathrm{r}$-values such as $\mathrm{Zn}-\mathrm{Na}(\mathrm{r}=-0.994), \mathrm{Zn}-\mathrm{K}(\mathrm{r}=-0.993)$ etc representing the mutual exchange of the respective metals with soil/water matrix. The remaining pairs indicated either positive or negative correlation showing their independent variations in the studied matrix.

Table 10. Correlation coefficient matrix of 14 physico chemical parameters of Kashmir lakes.

\begin{tabular}{|c|c|c|c|c|c|c|c|c|c|c|}
\hline & $\mathrm{Na}$ & $\mathbf{K}$ & $\mathrm{Ca}$ & Mg & $\mathrm{Fe}$ & $\mathbf{P b}$ & $\mathrm{Cu}$ & Zn & $\mathbf{N i}$ & $\mathrm{Cd}$ \\
\hline \multirow{2}{*}{$\mathrm{K}$} & 0.890 & & & & & & & & & \\
\hline & 0.302 & & & & & & & & & \\
\hline \multirow{2}{*}{$\mathrm{Ca}$} & 0.622 & 0.911 & & & & & & & & \\
\hline & 0.573 & 0.271 & & & & & & & & \\
\hline \multirow{2}{*}{$\mathrm{Mg}$} & 1.000 & 0.884 & 0.613 & & & & & & & \\
\hline & 0.007 & 0.309 & 0.580 & & & & & & & \\
\hline $\mathrm{Fe}$ & 0.588 & 0.890 & 0.839 & 0.581 & & & & & & \\
\hline \multirow{2}{*}{$\mathrm{Pb}$} & -0.203 & 0.266 & 0.641 & -0.214 & 0.904 & & & & & \\
\hline & 0.870 & 0.828 & 0.557 & 0.863 & 0.282 & & & & & \\
\hline \multirow{2}{*}{$\mathrm{Cu}$} & 0.779 & 0.979 & 0.975 & 0.772 & 0.030 & 0.456 & & & & \\
\hline & 0.431 & 0.130 & 0.142 & 0.439 & 0.981 & 0.699 & & & & \\
\hline \multirow{2}{*}{$\mathrm{Zn}$} & -0.994 & -0.933 & -0.701 & -0.993 & 0.515 & 0.098 & -0.841 & & & \\
\hline & 0.067 & 0.234 & 0.506 & 0.075 & 0.655 & 0.937 & 0.364 & & & \\
\hline $\mathrm{Ni}$ & 0.968 & 0.666 & 0.395 & 0.975 & 0.444 & 0.163 & 0.536 & 0.900 & & \\
\hline \multirow{2}{*}{$\mathrm{Cd}$} & 0.468 & 0.014 & -0.401 & 0.479 & -0.987 & -0.960 & -0.189 & -0.372 & 0.859 & \\
\hline & 0.690 & 0.991 & 0.737 & 0.682 & 0.102 & 0.180 & 0.879 & 0.757 & 0.343 & \\
\hline \multirow{2}{*}{ Co } & -0.002 & -0.458 & -0.785 & 0.009 & -0.796 & -0.979 & -0.629 & 0.108 & 0.999 & 0.882 \\
\hline & 0.999 & 0.697 & 0.426 & 0.994 & 0.413 & 0.132 & 0.567 & 0.931 & 0.031 & 0.312 \\
\hline
\end{tabular}

\subsection{Statistical Dimension and Inferences}

Data on a few selected parameters was treated to express statistical confidence and inferences drawn thereof, by calculating standard deviation of inter seasonal and inter lake variation in $\mathrm{pH}, \mathrm{TDS}, \mathrm{Cl}^{-}, \mathrm{SO}_{4}{ }^{2-}, \mathrm{Ca}^{2+} \mathrm{Na}^{+}, \mathrm{Mg}^{2+}, \mathrm{K}^{+}, \mathrm{DO}$, BOD, COD.

The parameters selected were to reflect:

(i) The in situ environment of the lake.

(ii) Biogeochemical processes occurring deeper in the bed-rock soil, at the water-bed rock interface and, vertically along the water matrix.

(iii) Alterations in the geochemical composition of water due to so called natural pollution and /or anthropogenic pollution.

(iv) Inter-lake comparison.

\subsection{The inferences}

$\mathrm{pH}$ varies from slightly acidic to slightly alkaline indicating moderate levels of photosynthesis regulating $\mathrm{CO}_{2}$ availability and $\mathrm{Ca}-\mathrm{CO}_{3}, \mathrm{Ca}-\mathrm{SO}_{4} \& \mathrm{Mg}-\mathrm{CO}_{3}, \mathrm{Mg}-\mathrm{SO}_{4}$ equilibrium facilitated by mineralization and cation exchange by organic acids mostly humic and fulvic acids.

Standard deviation (SD) for $\mathrm{SO}_{4}$ is also randomly distributed indicating chemical weathering of rock salt and its mobility to slightly acidic aqueous phase.

Interlake and inter-season variation of DO (Table 2) show 
better precision for Mangla and Baghsar while lesser for Banjosa, BOD is more precise for Banjosa and Baghsar but less for Mangla. COD also repeats BOD pattern, Mangla and Baghsar boast of dual anoxic-conditions of the water-rock soil interface and anthropogenic impact while Banjosa shows aerobic activity at the interface and also deeper in the soil. These trends are of preliminary and tentative nature until more frequent intera-seasonal sampling is done to ascertain intra-seasonal variation and also a better understanding of the nature of biogeochemical processes operating in the water system, and quantify anthropogenic impact and its considerable attenuation by dilution.

A discerning look at SD data (Table 2) brings up a pattern where the SD values for almost all the variables match for any two of the three lakes implying thereby that a combination of any two of the three lakes (i) do not differ in situ environment; (ii) are of similar rock soil composition; (iii) receive same degree of anthropogenic pollution and (iv) undergo equal levels of physical and chemical weathering.

\section{Conclusions}

Preliminary study of biogeochemical processes of three lakes and their intra and inter lake biogeochemical processes operating in their hydro and lithospheres indicate the existence of sound eco equilibrium between these processes. The natural system is nevertheless severely strained by anthropogenic activity involving variegated land use for urban settlements and industrialization, adding sewage and effluents, into these lakes.

The physicochemical study of some parameters of the lakes show high SD symptomatic of systematic error suggesting for more closely spaced sample taking over the seasons so as to precise the data and carry out more significant data tests and also enhance our ability to monitor and predict the 'straying' of any of the processes and, take remedial measures.

\section{References}

[1] M. N. González-Alcaraz, C. H. Miguel, \& J. Álvarez-Rogel, When liming and revegetation contribute to the mobilisation of metals: Learning lessons for the phytomanagement of metal-polluted wetlands. Journal of Environmental Management, 15, 72-80, 2013.

[2] J. M. Arocena, J. M. van Mourik, \& Á. Faz Cano. Granular soil structure indicates reclamation of degraded to productive soils: A case study in Southeast Spain. Canadian Journal of Soil Science, 92, 243-251, 2012.

[3] F. Degryse, E. Smolders, \& R. D. Parker. Partitioning of metals $(\mathrm{Cd}, \mathrm{Co} ., \mathrm{Cu}, \mathrm{Ni}, \mathrm{Pb}, \mathrm{Zn})$ in soils: concepts, methodologies, prediction and applications-A review. European Journal of Soil Science, 60, 590-612, 2009.

[4] C. M. Laluraj, \& G. Gopinath. Assessment of seasonal variation of groundwater quality of Pheretic aquifer-A river basin system. Environmental Monitoring and Assessment, 117, 45-57, 2006.
[5] S. Mahboob. Seasonal changes in planktonic life and water chemistry of Ajmal fish farm, Samundri road, Faisalabad. M.Sc. Thesis, Agri. Univ., Faisalabad, 1986.

[6] S. Mahboob, A. N. Sheri, M. B. Sial, \& M. Javed. Influence of physico-chemical factors on the dray weight of planktonic biomass in a commercial fish farm. Pakistan Journal of Agricultural Sciences, 25, 271-278, 1988 b.

[7] S. Mahboob, A. N. Sheri, M. B. Sial, M. Javed, \& M. Afzal. Seasonal changes in physico-chemistry and planktonic life of a commercial fish farm. Pakistan Journal of Agricultural Sciences, 25, 22-27, 1989a.

[8] S. Mahboob. Influence of fertilizer and artificial feed on the growth performance in composite culture of major, common and some Chinese carps. Ph. D. Thesis, Agriculture. University, Faisalabad, 1992.

[9] S. Mahboob, \& A. N. Sheri. Effect of fertilizer and artificial feed on the seasonal distribution of planktonic life in fish ponds. Pakistan Journal of Biological Sciences 5, 461-263, 2001.

[10] M. Latif. Comparison of Physico-chemical and biological aspects of two fish ponds fertilized with broiler droppings and N: P: K (25:25:0). M.Sc. Thesis, Agriculture. University, Faisalabad, 1990.

[11] M. Hassan. Effect of pond fertilization by broiler droppings on growth performance and meat quality of major carps. Ph.D. Thesis, Agriculture. University, Faisalabad, 1998.

[12] M. A. Mirza, M. Y. Khuhawar, \& R. Arain. Quality and distribution of lead in underground water Kashmir. Asian Journal of Chemistry, 20, 5915-5923, 2008.

[13] M. A. Mirza, M. Y. Khuhawar, \& R. Arain, Quality of spring water in the catchment areas of Indus River. Asian Journal of Chemistry, 19, 5279-5304, 2007.

[14] M. A. Mirza, G. M. Arain, \& M. Y. Khuhawar. Comparative physicochemical study of five main Ponds of District Bhimber Azad Jammu \& Kashmir. Journal of Chemical Society of Pakistan, 28, 430-434, 2006.

[15] M. A. Mirza, G. M. Arain, \& M.Y. Khuhawar. Hydrochemistry of Snowmelt in Sudhanoti \& Poonch Districts of Azad Kashmir Pakistan. Sindh University Research Journal (Science Series), 38, 25-32, 2006.

[16] M. A. Mirza, G. M. Arain, \& M. Y. Khuhawar. Chemistry of Torrents Water in the State of Azad Jammu \& Kashmir, Pakistan. The Nucleus, 44, 25-31, 2007.

[17] M. A. Mirza, M. Y. Khuhawar, \& A. J. Kandhro. Quality of Rain Water and its Suitability for Drinking and Agricultural use in District Bhimber Azad Kashmir, Pakistan. Pakistan Journal of Analytical Chemistry, 6, 72-79, 2005.

[18] H. A. Muhlhauser, A. Herpic, N. Mladinic, P. N. Montecino, \& S. Cabrera. Water quality and limnological features of a high altitude Andean lake, Chungard in northern Chile. Rev. Chil. Hist. Nat., 68, 369-289. 1995.

[19] C. D. Jersabek, \& R. Schabetsberger. Limnological aspects of an alpine Karst lake with extreme changes in water level. Limnologica, 26, 1-13, 1996.

[20] http://www.ajk.gov.pk/main/index.html 
[21] J. D. Hem. Study and Interpretation of the Chemical Characteristics of Natural Water, USGS Water Supply, p. 2254, 1985.

[22] G. D. Cooke, E. B. Welch, S.A. Peterson \& P. R. Newroth. Restoration and Management of Lakes and Reservoirs. 2nd Ed. Lewis Publishers, Boca Raton, FL. 548 pp. 1993.

[23] M. V. Gibbons, H. L. Gibbons, M. D. Sytsma. A Citizens' Manual for Developing Integrated Aquatic Vegetation Management Plans. First Ed. Prepared for Washington Department of Ecology Water Quality Program, 1994.

[24] U. S. Environmental Protection. Agency Volunteer Lake Monitoring: A Methods Manual. EPA 440/4-91-002. 1991.

[25] H. L. Edmiston, V. B. Meyers. Florida Lakes: A Description of Lakes, Their Processes, and Means of Protection. Water Quality Management and Restoration, Florida Department of Environmental Regulation, Tallahassee, Fl. 29 pp. 1993.

[26] North American Lake Management Society. NALMS Management Guide for Lakes and Reservoirs. Alchua, FL. 42 pp, 1989.

[27] M. A. Khan, \& D. P. Zutshi. Primary productivity and trophic status of a Kashmir Himalayan lake. Hydrobiologia 68, 3-8, 1980.

[28] D. P. Zutshi, K. K. Vass, Limnological studies on Dal Lake Sirinagar Indian. Natl. Sci. Acad B, Biol. Sci. 48, 234-241, 1982.

[29] S. M. Leghari, A. Bano, M. Y. Khuhawar, \& T. M. Jahangir. Limnological Study of Tatta Pani Hot Spring and River Punch at Tatta Pani Vilalge, District Punch, Azad Kashmir, Pakistan. Scientific Khyber, 13, 73-85, 2000.

[30] C. S. Meddlicott. Notes on the Sub-Himalayan series in the Jammu. (Jammoo) Hills. Rec. Geol. Surv. (India). 9, 49-57, 1876.

[31] R. Lydekker. The Geology of Kashmir and Chamba territories and the British district of Kaghan. Mem. Geol. Surv. India, 22, $1-334.1883$.
[32] C. C. Middlemiss. The geology of Hazara and the Black Mountains. Mem. Geol. Surv. India. 26, 1-302, 1896.

[33] D. N. Wadia. North Punjab and Kashmir. Rec. Geol. Surv. India, 62,152-156, 1928.

[34] M. Ashraf, M. N. Chaudhry, \& K. A. Qureshi. Stratigraphy of Kotli area of Azad Kashmir and its correlation with standard type area of Pakistan. Kashmir Jour. Geol.1, 19-30, 1983.

[35] K. Kumar, D. S. Rawat, R. Joshi. Chemistry of spring water in Almora, Central Himalaya, India. Environ. Geol. 31(3/4), 150156, 1997.

[36] APHA, Standard Methods for Examination of Water and Wastewater, American Public Health Association, Washington DC, edn. 17, 1497. 1989.

[37] F. J. Stevenson. Humus Chemistry, Willey Interscience Publications, New, 1982.

[38] M. M. Kononova. Soil organic Matter: Its Nature, Its role in Soil Fertility, 2nd Ed., Pergammon, Oxford, 1966.

[39] A. Saleh, F. Al-Ruwaih, M. Shehata. Hydrogeochemical processes operating within the main aquifers of Kuwait. J. Arid Environ. 42, 195-209,1999.

[40] G. Gilly, G. Corrao, \& S. Favilli. Concentrations of nitrates in drinking water and incidence of gastric carcinomas. First descriptive study of the Piemonate Region, Italy. Science of the Total Environment, 34, 35-48, 1984.

[41] K. R. Karanth. Groundwater assessment, development and management. Tata McGraw Hill New Delhi, pp720, 1987.

[42] H. M. Ragunath. Groundwater. Wiley Eastern Ltd, New Delhi. pp563. 1987.

[43] Collins, A. Jenkins, The impact of agricultural land use on stream chem-istry in the middle Hills of the Hima-layas, Napal. J Hydrol 185,71-86,1996.

[44] C. J. Pilbeam, P. J. Gregory, R. C. Munankarmy, \& B. P. Tripathi. Leaching of nitrate from cropped rainfed terraces in the mid-hills of Nepal. Nutrient Cycling in Agroecosystems, 69, 221-232, 2004 